\title{
CULTURA ALIMENTARIA: CLAVE PARA EL DISEÑO DE ESTRATEGIAS DE MEJORAMIENTO NUTRICIONAL DE POBLACIONES RURALES
}

\section{FOOD CULTURE: KEY FOR THE DESIGN OF NUTRITIONAL IMPROVEMENT STRATEGIES FOR RURAL POPULATIONS}

\author{
Ma. Elena Calderón-Martínez ${ }^{1}$, O. Rey Taboada-Gaytán ${ }^{1 *}$, Adrián Argumedo-Macías ${ }^{1}$, \\ Enrique Ortiz-Torres ${ }^{1}$, P. Antonio López ${ }^{1}$, Carmen Jacinto-Hernández ${ }^{2}$
}

\begin{abstract}
${ }^{1}$ Colegio de Postgraduados. Campus Puebla. Km 125.5 Carretera Federal México-Puebla (actualmente Boulevard Forjadores de Puebla). 72760. Puebla, Puebla, México. (mec_mar@ hotmail.com, oswaldoreytg@gmail.com, argumedomac@hotmail.com, enriqueortiz@ colpos.mx; palopez@colpos.mx). ${ }^{2}$ Instituto Nacional de Investigaciones Forestales, Agrícolas y Pecuarias, INIFAP. Avenida Progreso 5, Colonia Barrio de Santa Catarina, Delegación Coyoacán, Distrito Federal. 04010. (jacinto.carmen@inifap.gob.mx)
\end{abstract}

\section{RESUMEN}

Actualmente se ejecutan programas sociales con enfoque alimentario, cuya meta es combatir la inseguridad alimentaria y sus consecuencias. En muchos casos no alcanzan su objetivo debido a una mala planeación y diseño; lamentablemente el bajo impacto impide mejorar la nutrición de los más vulnerables: los menores de edad. El objetivo de este estudio fue proponer una alternativa en el diseño y la planificación de estrategias de mejora nutricional basada en el análisis de la cultura alimentaria local para incrementar la efectividad del programa. Se aplicaron encuestas a 74 madres de familia de niños preescolares y escolares en Tochimilco, Puebla, México, para obtener información sobre características generales y alimentación familiar. Se encontró que la muestra estudiada pertenece a un núcleo familiar de cinco personas en promedio, cuyo principal medio de vida es la agricultura. Uno de los cultivos principales en la región es el amaranto; este no es consumido de forma regular, debido al desconocimiento de formas de preparación y de beneficios en la salud. Se concluyó que el análisis de la cultura alimentaria facilita el diseño de una propuesta de mejora nutricional con alta efectividad. Específicamente en Tochimilco, amaranto, maíz, frijoles y frutas son elementos ideales para un programa nutricional.

Palabras clave: Amaranthus hypochondriacus L., desnutrición infantil, diagnóstico situacional, estrategia de desarrollo, programas alimentarios, recursos locales.

* Autor responsable * Author for correspondence. Recibido: marzo, 2016. Aprobado: agosto, 2016. Publicado como ARTÍCULO en ASyD 14: 303-321. 2017.
Currently, social programs with a focus on food are executed with the goal of fighting food insecurity and its consequences. In many cases they do not reach their objective due to bad planning and design; regretfully the low impact prevents improving the nutrition of the most vulnerable, minors. The objective of this study was to propose an alternative for the design and planning of strategies for nutritional improvement based on the analysis of local food culture to increase the effectiveness of the program. Surveys were applied to 74 mothers of preschool and school age children in Tochimilco, Puebla, México, in order to obtain information about general characteristics and the family diet. It was found that the sample studied belongs to a family nucleus of five people in average, whose main livelihood is agriculture. One of the main crops in the region is amaranth; it is not consumed regularly, due to the lack of knowledge of ways to prepare it and its health benefits. It was concluded that the analysis of the food culture facilitates the design of a proposal for nutritional improvement with high effectiveness. Specifically in Tochimilco, amaranth, maize, beans and fruits are ideal elements for a nutritional program.

Key words: Amaranthus hypochondriacus L., child malnutrition, situational diagnosis, development strategy, food programs, local resources.

\section{INTRODUCTION}

The social programs with a focus on food are
strategies for the nutritional development of
the population (Ruel and Alderman, 2013). Each one addresses particular problems; however, the 


\section{INTRODUCCIÓN}

$\mathrm{L}$ os programas sociales con enfoque alimentario son estrategias para el desarrollo nutricional de la población (Ruel y Alderman, 2013). Cada uno aborda problemas particulares; no obstante, el objetivo primordial es la seguridad alimentaria (Godfray et al., 2010). Su creación se da por diversas razones: controlar o reducir un problema en aumento, cumplir una política pública, evidenciar el gasto público, entre otras (Miller et al., 2012; Mishra et al., 2013). La causa por la que se crean dichos programas define el impacto sobre la población objetivo, así como en la metodología empleada para el diseño e implementación del programa.

En el proceso metodológico de un programa social, la etapa de la planificación es la fase que más contribuye al impacto final (Alberich et al., 2014; González et al., 2014); por lo tanto, si existen problemas en esta etapa inicial, las probabilidades de tener una baja efectividad del programa se incrementan. Entre los problemas ocasionados por una mala planificación se encuentran: apoyos reducidos y mal asignados, problemas de diseño, falta de focalización geográfica, confusión de objetivos, multiplicidad de programas y superposición (Barquera et al., 2001; Alcázar, 2007); como consecuencia, se afecta de manera negativa la economía del país donde se implementan este tipo de programas mal diseñados (De la Cruz, 2013). Lo anterior marca la necesidad de un diseño y planificación de programas que incremente la efectividad de los mismos al momento de su puesta en marcha (Rivera-Dommarco et al., 2013).

El conocimiento de la cultura alimentaria de una región puede ser elemento clave en la planificación y efectividad (Vilaplana, 2011) de los programas sociales diseñados para mejorar la nutrición de la población objetivo, pues a través del conocimiento de esta se pueden prevenir errores de ejecución durante la aplicación del programa y aumentar su efectividad. La cultura alimentaria se entiende como los usos (lujo, placer), tradiciones (religión), costumbres (estatus social, interacción social) y elaboraciones simbólicas de los alimentos (Marín et al., 2004; Vilaplana, 2011) y donde además influye el ciclo productivo de los alimentos del contexto en particular. La cultura alimentaria se puede conocer a través de un diagnóstico situacional, el cual es una etapa básica en primordial objective is food security (Godfray et al., 2010). Their creation takes place because of various reasons: to control or reduce an increasing problem, to fulfill a public policy, to evidence public spending, among others (Miller et al., 2012; Mishra et al., 2013). The reason why these programs are created defines the impact on the target population, as well as the methodology employed for the design and implementation of the program.

In the methodological process of a social program, the stage of planning is the phase that contributes most to the final impact (Alberich et al., 2014; González et al., 2014); therefore, if there are problems during this initial phase, the probabilities of having low effectiveness of the program increase. Among the problems caused by bad planning, there are: reduced and ill-assigned supports, design problems, lack of geographic focalization, confusion of objectives, multiplicity and superposition of programs (Barquera et al., 2001; Alcázar, 2007); as consequence, the country's economy where this type of ill-designed programs are implemented is affected negatively (De la Cruz, 2013). This marks the need for the design and planning of programs that increase their effectiveness at the time of their implementation (Rivera-Dommarco et al., 2013).

The knowledge of the food culture of a region can be a key element in the planning and effectiveness (Vilaplana, 2011) of the social programs designed to improve the nutrition of the target population, since through its knowledge errors in execution during the application of the program can be prevented and its effectiveness could increase. The food culture is understood as the uses (luxury, pleasure), traditions (religion), customs (social status, social interaction), and symbolic elaboration of foods (Marín et al., 2004; Vilaplana, 2011), and where the productive cycle of the foods from the context in particular also has an influence. The food culture can be understood through a situational diagnosis, which is a basic stage in the planning of strategies or programs (Quintero et al., 2014), since it clarifies regional problems and allows discerning possible solutions.

Currently there are many food programs in México, whose planning is based on factors different from the food culture and local resources. Examples of these programs are microcredits (Medina and Florido, 2010), provided to the majority of people without specific characteristics; the national Prospera 
la planificación de estrategias o programas (Quintero et al., 2014), ya que aclara problemas regionales y permite vislumbrar posibles soluciones.

Actualmente existen muchos programas alimentarios en México, cuya planeación está basada en factores distintos a la cultura alimentaria y los recursos locales. Ejemplos de estos programas son los microcréditos (Medina y Florido, 2010) proporcionados a la mayoría de personas sin características específicas; el programa nacional Prospera, que proporciona recursos monetarios uniformes y condicionados (DOF, 2013); el Programa Nacional "México sin Hambre" 2014-2018 se basa en la participación social, la coordinación interinstitucional e intergubernamental, la territorial, el enfoque productivo, la innovación y la estrategia de cobertura (DOF, 2014); además, otros programas que están incluidos en la Cruzada contra el Hambre (diseñada e implementada para promover la seguridad alimentaria) son el Programa de Desarrollo Humano Oportunidades (PDHO, 2002-2014), el Programa de Apoyo Alimentario (PAL, 2003 a la fecha), el Programa de Abasto Social de Leche (PASL, 1944 a la fecha), y el Programa de Abasto Rural (PAR, 1980 a la fecha), los cuales solo consideran edad, vulnerabilidad, ingreso y número de habitantes (SEDESOL, 2012).

Estos son algunos de los programas destacados en el país en cuanto a cobertura; sin embargo, se ha comprobado que no alcanzan los resultados esperados en todos los casos. Gutiérrez et al. (2012) reportan en la ENSANUT 2012 una disminución de la desnutrición infantil; empero, a nivel regional Oportunidades logró "un impacto muy limitado" en la disminución de la desnutrición (García-Parra et al., 2015). En otro caso, Gertler (2004) observó un efecto positivo en la salud de niños de siete estados de la República Mexicana; no obstante, no se tiene evidencia de si la causa de este efecto fue el beneficio monetario o el cambio de conducta de los beneficiarios. También se ha observado el aumento de la pobreza alimentaria pese al programa Oportunidades (Bracamontes et al., 2014).

Aun cuando existe poca información sobre la evaluación de programas alimentarios, lo cierto es que la malnutrición prevalece; según la última Encuesta de Salud y Nutrición de 2012 existe una prevalencia nacional en menores de cinco ańos de bajo peso $(2.8 \%)$, baja talla $(13.6 \%)$ y emaciación (1.6\%) (Gutiérrez et al., 2012). La información disponible program, which provides uniform and conditioned monetary resources (DOF, 2013); the National Program "México sin Hambre" 2014-2018 is based on social participation, interinstitutional and intergovernmental, and territorial coordination, productive approach, innovation and coverage strategy (DOF, 2014); in addition, other programs that are included in the Crusade against Hunger (Cruzada contra el Hambre, designed and implemented to promote food security) are the Oportunidades Human Development Program (Programa de Desarrollo Humano Oportunidades, PDHO, 2002-2014), the Food Support Program (Programa de Apoyo Alimentario, PAL, 2003 to date), the Milk Social Supply Program (Programa de Abasto Social de Leche, PASL, 1944 to date), and the Rural Supply Program (Programa de Abasto Rural, PAR, 1980 to date), which only consider age, vulnerability, income and number of inhabitants (SEDESOL, 2012).

These are some of the outstanding programs in the country in terms of coverage; however, it has been proven that they do not attain the results expected in every case. Gutiérrez et al. (2012) report in the ENSANUT 2012 a decrease of child malnutrition; nevertheless, at the regional level Oportunidades achieved "a very limited impact" on the decrease of malnutrition (García-Parra et al., 2015). In another case, Gertler (2004) observed a positive effect in the health of children from seven states of the Mexican Republic; however, there is no evidence of whether the cause of this effect was the monetary benefit or the change in behavior of the beneficiaries. The increase of food poverty has also been observed despite the Oportunidades program (Bracamontes et al., 2014).

Even when there is little information about the evaluation of food programs, what is true is that malnutrition prevails; according to the last Survey on Health and Nutrition 2012 there is a national prevalence in children younger than five of low weight (2.8\%), small size (13.6\%) and emaciation (1.6\%) (Gutiérrez et al., 2012). The information available about the planning and design of the programs which support the increase in its effectiveness is insufficient and inadequate; likewise, there is a very limited number of strategies and programs that prioritize the regional characteristics and the food culture. For this reason, it is necessary to generate information about the importance of the food culture in the 
sobre la planeación y el diseño de los programas que apoye al incremento de su efectividad es insuficiente e inadecuada; asimismo, existe un número muy limitado de estrategias y programas que prioricen las características regionales y la cultura alimentaria. Por esta razón, es necesario generar información sobre la importancia de la cultura alimentaria en la implementación de un programa social que promueva la seguridad alimentaria.

El objetivo de esta investigación fue proponer una alternativa en el diseño y la planeación de programas sociales con enfoque alimentario que coadyuve al incremento de su efectividad. En la información que se presenta en este escrito se tomó como elemento clave la cultura alimentaria de la población, las actividades productivas y los recursos locales. El municipio de estudio tiene ciertas características que pueden ser similares a otras zonas; por lo tanto, esta alternativa innovadora puede implementarse también en otros ámbitos. El propósito último es coadyuvar en el aumento del impacto positivo de nuevos programas o estrategias nutricionales en las zonas rurales ${ }^{3}$.

\section{MÉTodos}

\section{Localización y características de la región del estudio}

La investigación se realizó en el municipio de Tochimilco, en el estado de Puebla, México, específicamente en tres localidades pertenecientes a la zona productora de amaranto (Amaranthus hypochondriacus L.). Tochimilco está situado en el centro-oeste del estado de Puebla, entre los paralelos $18^{\circ} 50^{\prime}$ y $19^{\circ} 02^{\prime} \mathrm{LN}$ y los meridianos $97^{\circ} 18^{\prime}$ y $97^{\circ} 27^{\prime} \mathrm{LO}$. Colinda con el estado de Morelos y los municipios de San Nicolás de los Ranchos, Atlixco y Tianguismanalco (Figura 1) (SEDESOL, 2011). Este municipio cuenta con una superficie total de $233.45 \mathrm{~km}^{2}$ y tiene 17,028 habitantes (INEGI, 2010). Dentro de la región se encuentran altitudes que van desde 1800 hasta $5500 \mathrm{msnm}$. El $44 \%$ de la superficie es utilizada para la agricultura y solo $3 \%$ es zona urbana. El $43 \%$ de la vegetación es bosque de pino en su mayoría y de pino-encino en un menor porcentaje (SEDESOL, 2011).

La principal actividad económica es la agricultura. Ocupa el segundo lugar a nivel nacional en producción de amaranto, solo detrás de Cuapiaxtla, municipio del estado de Tlaxcala. En 2014 la producción del implementation of a social program that promotes food security.

The objective of this study was to provide an alternative in the design and the planning of social programs with a focus on food that contributes to increasing their effectiveness. In the information presented in this study, the population's food culture, productive activities and local resources were taken as key elements. The municipality of study has certain characteristics that can be similar to other zones; therefore, this innovating alternative can also be implemented in other areas. The ultimate purpose is to contribute to the increase of positive impact of new nutritional programs or strategies in rural areas ${ }^{3}$.

\section{Methods}

\section{Location and characteristics of the study region}

The research was performed in the municipality of Tochimilco, in the state of Puebla, México, specifically in three localities that belong to the amaranth producing zone (Amaranthus hypochondriacus L.). Tochimilco is located in the center-west of the state of Puebla, between parallels $18^{\circ} 50^{\prime}$ and $19^{\circ} 02^{\prime} \mathrm{N}$ and the meridians $97^{\circ} 18^{\prime}$ and $97^{\circ} 27^{\prime} \mathrm{W}$. It neighbors with the state of Morelos and the municipalities of San Nicolás de los Ranchos, Atlixco and Tianguismanalco (Figure 1) (SEDESOL, 2011). This municipality has a total surface of $233.45 \mathrm{~km}^{2}$ and has 17, 028 inhabitants (INEGI, 2010). Within this region, altitudes range from 1800 to 5500 masl. Of the surface, $44 \%$ is used for agriculture and only $3 \%$ is urban. Of the vegetation, $43 \%$ is pine forest in its majority and pine-oak in a lower percentage (SEDESOL, 2011).

The main economic activity is agriculture. It occupies the second place at the national level in amaranth production, only after Cuapiaxtla, municipality in the state of Tlaxcala. In 2014 the municipality's production was $1095 \mathrm{t}$ and its average yield was one $\mathrm{tha}^{-1}$ (SIAP, 2014).

The municipality is made up of 24 localities, of which three are urban and 21 rural. The study was carried out in three communities, classified, according to SEDESOL (2013), as two rural ones and one urban: Santiago Tochimizolco (C1), San Miguel Tecuanipa (C2) and La Magdalena Yancuitlalpan (C3), respectively. The population is 747 inhabitants 


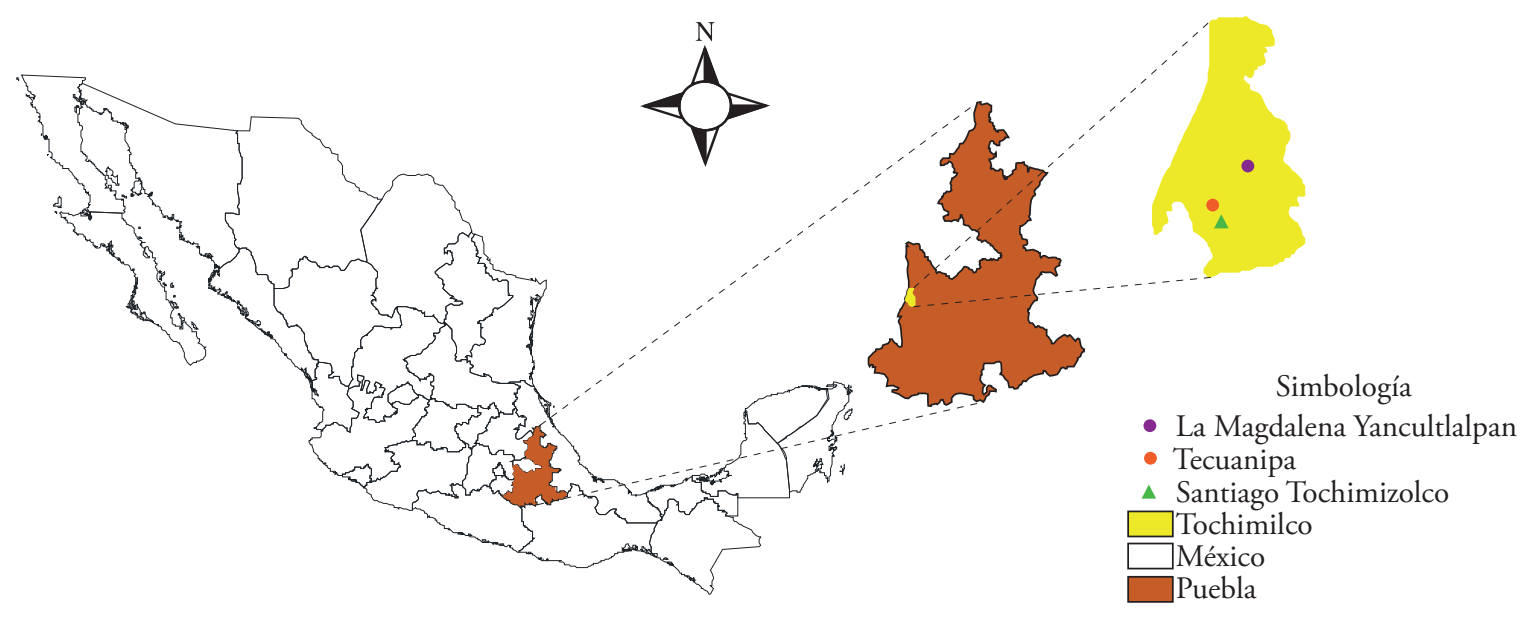

Figura 1. Localización de las comunidades del estudio.

Figure 1. Location of the communities of study.

municipio fue de $1095 \mathrm{t}$ y su rendimiento promedio fue de una $\mathrm{t} \mathrm{ha}^{-1}$ (SIAP, 2014).

El municipio está conformado por 24 localidades, de las cuales tres son urbanas y 21 rurales. El estudio se llevó a cabo en tres comunidades, clasificadas, según SEDESOL (2013), como dos rurales y una urbana: Santiago Tochimizolco (C1), San Miguel Tecuanipa (C2) y La Magdalena Yancuitlalpan (C3), respectivamente. La población es de 747 habitantes en C1, de 1378 en C2, y de 2210 en C3. La Magdalena Yancuitlalpan está clasificada por SEDESOL (2013) como zona urbana; sin embargo, posee características, como el uso del suelo predominantemente agrícola, que hacen considerarla como población rural (Estrada, 1992). Las tres localidades tienen grado de marginación alto y rezago social medio (SEDESOL, 2013). Según CONAPO (2010) y CONEVAL (2010) se refiere a la falta de oportunidades de desarrollo y a las carencias sociales (aspectos de educación, vivienda y servicios) que las localidades mantienen.

\section{Población y tamaño de muestra del estudio}

En esta investigación no se calculó tamaño de muestra, sino que la información necesaria para conocer y precisar la cultura alimentaria local se obtuvo de 74 amas de casa pertenecientes a las tres localidades (C1, C2, C3) elegidas por su inscripción voluntaria al estudio en la primera reunión informativa. in C1, 1378 in C2, and 2210 in C3. Magdalena Yancuitlalpan is classified by SEDESOL (2013) as an urban zone; however, it has characteristics, such as the predominantly agricultural land use, which make it be considered as rural population (Estrada, 1992). The three localities have a high degree of marginalization and medium social backwardness (SEDESOL, 2013). According to CONAPO (2010) and CONEVAL (2010) it refers to the lack of opportunities for development and to social scarcities (aspects of education, housing and services) that the localities have.

\section{Population and sample size of the study}

In this study the size of the sample was not calculated, but rather the necessary information to understand and determine the local food culture was obtained from 74 housewives that belong to the three localities $(\mathrm{C} 1, \mathrm{C} 2$, C3) chosen by their voluntary inscription to the study during the first informative meeting.

Field research began with the contact with municipal authorities, with the purpose of informing about the study's objectives and obtaining their authorization to carry it out in the three localities selected. For the selection of the localities the following were taken as criteria: amaranth production, years this crop has been sown, and participation of the people in research projects or previous promotion activities. Later, the auxiliary authorities from each community and the directors 
La investigación de campo inició con el contacto con las autoridades municipales, con el propósito de informar acerca de los objetivos del estudio y de obtener su autorización para poder llevarlo a cabo en las tres localidades seleccionadas. Para la selección de las localidades se tomaron como criterios: producción de amaranto, años que llevan sembrando este cultivo y participación de la gente en proyectos de investigación o actividades de fomento anteriores. Posteriormente se contactó a las autoridades auxiliares de cada comunidad y a directivos de instituciones preescolares y escuelas primarias con el fin de obtener el permiso para trabajar con las madres de familia; asimismo, fue solicitado el espacio para trabajar, mismo que fue proporcionado por las autoridades municipales locales, ubicado en cada una de las presidencias auxiliares.

Se trabajó con un grupo de madres de familia "invitadas a participar" (Martínez-Salgado, 2012), de las escuelas primarias "Benito Juárez", "Xicoténcatl" y "Vicente Guerrero", y de los jardines de niños "Cuauhtémoc", "Yanguik Xochikoskatl" y "Agustín Melgar" en las comunidades C1, C2 y C3, respectivamente. Se obtuvieron datos sobre la alimentación de las familias y los recursos locales disponibles. Se recopiló la información con mujeres adultas de las comunidades, quienes son madres de familia de alumnos en edad preescolar y escolar. Se eligió trabajar con ellas debido al rol fundamental que desempeñan como encargadas de la alimentación y salud de los integrantes de la familia (Pérez et al., 2007). En la comunidad C1 se aplicaron 25 encuestas; en C2, 21; y en C3, 28.

\section{Materiales}

La información fue colectada durante los meses de febrero a mayo de 2015 mediante la aplicación de una encuesta semi-estructurada la cual fue elaborada con el objetivo de conocer la cultura alimentaria de la población y se aplicó a madres de familia dedicadas a labores del hogar y encargadas de la preparación de la dieta familiar. Se incluyeron preguntas generales sobre la familia, aspectos nutricionales, actividades productivas y preguntas enfocadas al consumo del amaranto, debido a que este es un cultivo local preponderante en la región.

Se utilizó el instrumento de frecuencia de consumo semanal para registrar algunos alimentos que from preschools and primary schools were contacted, with the purpose of attaining the permission to work with the female head of family; likewise, the space to work in was requested, which was provided by the local municipal authorities, located in each one of the auxiliary presidencies.

Work was performed with a group of female heads of family who were "invited to participate" (Martínez-Salgado, 2012), from the primary schools "Benito Juárez", "Xicoténcatl" and "Vicente Guerrero", and the preschools "Cuauhtémoc", "Yanguik Xochikoskatl" and "Agustín Melgar" in the communities C1, C2 and C3, respectively. Data were obtained about the families' diet and the available local resources. Information was gathered with adult women from the communities, who are mothers of students in preschool and school age. It was chosen to work with them because of the fundamental role they play as the ones in charge of the diet and health of the members of the family (Pérez et al., 2007). In the community $\mathrm{C} 1,25$ surveys were applied; in $\mathrm{C} 2$, 21 ; and in $\mathrm{C} 3,28$.

\section{Materials}

The information was gathered during the months of February to May 2015, through the application of a semi-structured survey which was elaborated with the objective of understanding the food culture of the population and was applied to the female heads of family devoted to household tasks and in charge of preparing the family diet. General questions were included about the family, nutritional aspects, productive activities, and questions focused on amaranth consumption, because this is a local crop prevalent in the region.

The instrument of frequency of weekly consumption was used to register some foods that the family units ingest, which helped to identify the deficit or excess of macronutrients; likewise, the economically accessible foods and local resources were explored, as well as data about maize production, amaranth production and causes for the low or null consumption of amaranth.

\section{Statistical analysis}

With the information obtained from the 74 surveys applied, descriptive statistics tools were 
ingieren las unidades familiares, lo que ayudó a identificar el déficit o excedente de los macronutrimentos; asimismo, se conocieron los alimentos económicamente accesibles y recursos locales, datos sobre la producción de maíz, producción de amaranto y los motivos del bajo o nulo consumo de amaranto.

\section{Análisis estadístico}

Con la información obtenida de las 74 encuestas aplicadas se emplearon herramientas de estadística descriptiva. Se obtuvieron frecuencias y promedios de las características generales de la población, de la producción de cultivos, de las características de la alimentación, y aspectos relacionados con el consumo de amaranto. Este análisis fue realizado en el programa Microsoft Excel 2013. Además, se aplicaron técnicas de estadística multivariada, específicamente el análisis de conglomerados mediante el procedimiento CLUSTER, agrupando con el método de mínima varianza dentro de grupos de Ward (Timm, 2002) y el análisis de factores principales (Härdle y Simmar, 2007) con el procedimiento FACTOR. En ambos casos se utilizó el software SAS (Statistical Analysis System), versión 9.1 (SAS Institute, 2002-2012).

\section{Resultados y Discusión}

A través de la encuesta semi-estructurada se identificaron rasgos característicos de la población de madres de familia de las tres comunidades. De manera general se aprecian valores promedio muy similares entre comunidades. En el Cuadro 1 se presentan las características generales de la población a la que se encuestó. La población que participó, en promedio, se encuentra en la etapa de edad adulta joven, con una escolaridad de educación media, y en la actualidad se dedican a labores del hogar; por lo mismo, alrededor de $100 \%$ son responsables de la alimentación de su núcleo familiar. En cuanto a la economía, la mayoría de las familias perciben un ingreso mensual menor a $\$ 1000.00$ M.N. por concepto de actividad laboral remunerada, aunque el ingreso familiar está complementado por apoyos gubernamentales obtenidos a través de diferentes programas; asimismo, se puede notar que hay familias que obtienen ingresos mayores. Las familias de las tres comunidades son de bajos recursos y de baja formación académica respecto a la media estatal, que es de 8.5 años. Es posible destacar employed. Frequencies and averages of the general characteristics of the population were obtained, of the production of crops, of the characteristics of the diet, and aspects related to amaranth consumption. This analysis was carried out in the Microsoft Excel 2013 software. In addition, multivariate statistical techniques were applied, specifically conglomerate analysis through the CLUSTER procedure, grouping with the minimum variance method within the Ward groups (Timm, 2002) and the principal factors analysis (Härdle and Simmar, 2007) with the FACTOR procedure. In both cases the SAS software (Statistical Analysis System), version 9.1 (SAS Institute, 2002-2012), was used.

\section{Results AND Discussion}

Through the semi-structured survey, characteristic features of the population of the female heads of family from the three communities were identified. In general quite similar mean values are seen between communities. In Table 1 the general characteristics of the population which was surveyed are presented. The population that participated, in average, is in the stage of young adult, with high school studies, and currently devoted to household chores; therefore, around $100 \%$ are responsible for the diet of their family nucleus. In terms of the economy, most of the families receive a monthly income of less than $\$ 1000.00$ MX pesos, from paid work activities, although the family income is complemented by government backing obtained through different programs; likewise, it can be seen that there are families that obtain higher income. The families from the three communities are of low resources and low academic training compared to the state mean, which is 8.5 years. It is possible to highlight that the social characteristics are highly similar among the survey respondents of the three communities.

Figure 2 shows the dendogram through which three groups formed with interviewees from the three communities of study are identified. Groups 1,2 and 3 were made up of 30, 19 and 25 survey respondents. When performing a multivariate variance analysis, significant differences were found between the groups identified (data not shown), contrasting with the descriptive analysis in which marked differences were not observed in the general characteristics. This can be because in the multivariate variance analysis 
Cuadro 1. Características generales de 74 madres de familia en tres localidades del municipio de Tochimilco, Puebla, México. 2015.

Table 1. General characteristics of 74 female heads of family in three localities of the municipality of Tochimilco, Puebla, México. 2015.

\begin{tabular}{|c|c|c|c|c|}
\hline Característica & Tochimizolco & $\begin{array}{c}\text { San Miguel } \\
\text { Tecuanipa }\end{array}$ & $\begin{array}{l}\text { La Magdalena } \\
\text { Yancuitlalpan }\end{array}$ & Total \\
\hline Media edad (años) & 33 & 33 & 34 & 33 \\
\hline Media escolaridad (años) & 7 & 8 & 7 & 7 \\
\hline \multicolumn{5}{|l|}{ Ocupación: } \\
\hline Ama de casa $(\%)$ & 27 & 18 & 28 & 73 \\
\hline Ama de casa y campo (\%) & 5 & 7 & 6 & 18 \\
\hline $\operatorname{Otras}^{\dagger}(\%)$ & 1 & 4 & 4 & 9 \\
\hline \multicolumn{5}{|c|}{ Ingreso mensual familiar (por actividad laboral remunerada): } \\
\hline Menos a $\$ 1000$ M.N. (\%) & 26 & 26 & 36 & 88 \\
\hline De $\$ 1001$ a $\$ 2500$ M.N. (\%) & 7 & 3 & 1 & 11 \\
\hline De $\$ 2501$ a $\$ 5000$ M.N. (\%) & 1 & 0 & 0 & 1 \\
\hline \multicolumn{5}{|l|}{ Responsable de alimentación familiar: } \\
\hline Encuestada (\%) & 32 & 27 & 38 & 97 \\
\hline Otra persona (\%) & 2 & 1 & 0 & 3 \\
\hline
\end{tabular}

${ }^{\dagger}$ Otras ocupaciones: comerciante y empleada. $*$ Other occupations: merchant and employee.

que las características sociales son altamente similares entre las encuestadas de las tres comunidades.

En la Figura 2 se observa el dendrograma a través del cual se identificaron tres grupos formados con entrevistadas de las tres comunidades del estudio. Los Grupos 1, 2 y 3 se integraron con 30, 19 y 25 encuestadas. Al realizar un análisis de varianza multivariado se encontraron diferencias significativas entre los grupos identificados (datos no mostrados), contrastante con el análisis descriptivo, en el cual no se observaron diferencias marcadas en las características generales. Esto puede deberse a que en el análisis de varianza multivariado se compararon los grupos con base en un mayor número de variables que en el análisis descriptivo. El promedio de integrantes en el núcleo familiar de las tres comunidades es de cinco personas y la presencia de menores en edad preescolar y escolar es de dos a tres infantes por unidad familiar. De acuerdo con la información obtenida en las 74 encuestas se encontró que hay 42 menores de 12 años en Santiago Tochimizolco, 37 en San Miguel Tecuanipa, y 62 en La Magdalena Yancuitlalpan, lo que da un total de 141 menores que están en riesgo de padecer algún tipo de malnutrición en cualquiera de sus dos vertientes: desnutrición u obesidad. A pesar de ser una zona rural, la familia promedio no es muy numerosa, por lo que los menores de edad pueden ser atendidos con mayor cuidado en el aspecto nutricional; en este sentido, la madre de familia es quien asume esta responsabilidad. groups were compared based on a higher number of variables than in the descriptive analysis. The average number of members in the family nucleus of the three communities is five people and the presence of preschool and school age minors is two to three children per family unit. According to the information obtained in the 74 surveys it was found that there are 42 children younger than 12 in Santiago Tochimizolco, 37 in San Miguel Tecuanipa, and 62 in La Magdalena Yancuitlalpan, which gives a total of 141 minors who are at risk of enduring some type of malnutrition in any of its two aspects: undernourishment or obesity. Despite it being a rural zone, the average family is not very numerous, so that the minors can be tended to with greater care in the nutritional aspect; in this sense, the female head of family is who takes on this responsibility.

The group formation in the dendogram was determined basically by the variables related to amaranth production and to the frequency of weekly consumption of the foods considered in the study. Three groups were formed at a distance of 0.1 of $r$-square. The groups that were established according to the surface and annual production of amaranth from each family, which were classified as low, medium and high amaranth production, based on the average yield per surface unit of amaranth; the lowest was $240 \mathrm{~kg} \mathrm{ha}^{-1}$ and the highest $4000 \mathrm{~kg} \mathrm{ha}^{-1}$. Group 1 is made up of families with low amaranth 
Análisis cluster

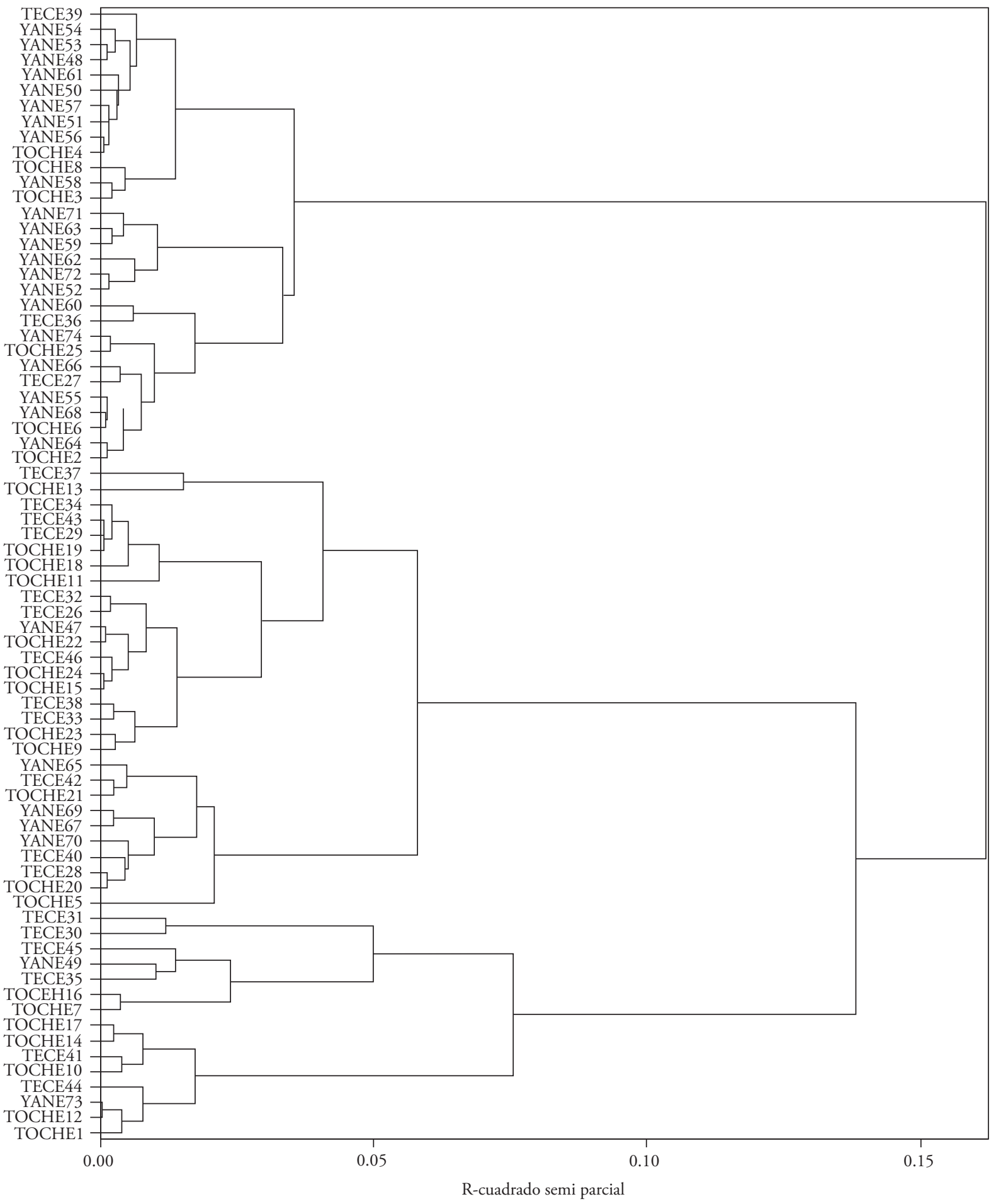

*TEC: San Miguel Tecuanipa; YAN: La Magdalena Yancuitlalpan; TOCH: Santiago Tochimizolco; E: Número de Encuesta. * *TEC: San Miguel Tecuanipa; YAN: La Magdalena Yancuitlalpan; TOCH: Santiago Tochimizolco; E: Number of survey.

Figura 2. Grupos identificados con las 74 familias en tres localidades del municipio de Tochimilco, Puebla, México. 2015.

Figure 2. Groups identified with the 74 families in three localities of the municipality of Tochimilco, Puebla, México. 2015. 
La formación de los grupos en el dendrograma fue determinada básicamente por las variables relacionadas a la producción de amaranto y a la frecuencia de consumo semanal de los alimentos considerados en el estudio. Se formaron tres grupos a una distancia de 0.1 de r-cuadrada. Los grupos se integraron de acuerdo con la superficie y producción anual de amaranto de cada familia, mismos que fueron clasificados como de baja, media y alta producción de amaranto, considerando el rendimiento promedio por unidad de superficie de amaranto; el más bajo fue de 240 $\mathrm{kg} \mathrm{ha}^{-1}$ y el más alto fue de $4000 \mathrm{~kg} \mathrm{ha}^{-1}$. El grupo 1 está conformado por familias con baja producción de amaranto, las cuales llevan 4.8 años en promedio produciéndolo, a diferencia del 2 , cuya producción es alta y lo han cultivado 7.6 años en promedio; finalmente, el 3 es de mediana producción. En cuanto a la frecuencia de consumo de alimentos, los grupos 1 y 2 presentan promedios muy similares; en cambio, la del 3 es más completa y balanceada, ya que consume alimentos saludables, como verduras, frutas, lácteos, queso y amaranto, con mayor frecuencia.

El agrupamiento de las unidades familiares, con base en las características relacionadas a los aspectos generales de las familias y a los patrones de consumo de alimentos puede permitir un enfoque mejor orientado al momento de diseñar estrategias de mejoramiento nutricional para las poblaciones rurales. Además, con el análisis de factores principales es posible identificar los más sobresalientes que influyen en la alimentación y su relación con las variables o indicadores más importantes, sobre los cuales enfocar la atención en los programas de mejoramiento nutricional.

El análisis de la información en este estudio indica una contradicción con la literatura relacionada con las características de las zonas rural y urbana. Pineda (2012) observó que las brechas entre estas traducen desigualdad y mantienen la pobreza; sin embargo, en este estudio se encontró que las tres comunidades en las que se trabajó, dos rurales y una urbana, tuvieron resultados similares en lo que se refiere a aspectos generales de las unidades familiares y características de las mismas, lo que permitió la formación de grupos de familias con base en sus similitudes (modos de vida prevalentemente rurales), independientemente de la comunidad donde radican y la clasificación, rural o urbana, que a esta se ha otorgado; estos resultados son similares a los de Urzúa et al. (2013). Las production, which have been producing it 4.8 years in average, in contrast with Group 2, whose production is high and have cultivated it 7.6 in average; finally, Group 3 is of medium production. In terms of the frequency of consumption of the foods, Groups 1 and 2 present very similar averages; instead, Group 3 is more complete and balanced, since it consumes healthy foods like vegetables, fruits, dairy, cheese and amaranth, with higher frequency.

The grouping of family units, based on characteristics related to the general aspects of the families and the consumption patterns of foods, can allow a better approach directed at the moment of designing strategies of nutritional improvement for the rural populations. In addition, with the principal factors analysis it is possible to identify the most outstanding ones that influence the diet and their relation with the most important variables or indicators, on which to focus the attention of the programs for nutritional improvement.

The information analysis in this study indicates a contradiction with the literature related to the characteristics of the rural and urban zones. Pineda (2012) observed that the gaps between these translate into inequality and maintain poverty; however, in this study it was found that the three communities where the study took place, two rural and one urban, had similar results in terms of general aspects of the family units and their characteristics, which allowed the formation of family groups based on their similarities (predominantly rural livelihoods), regardless of the community where they reside and the classification, rural or urban, that they have been given; these results are similar to those by Urzúa et al. (2013). The variations that were found within the families were not necessarily because of their zone, but rather due to other factors: characteristics of the families, such as number of children, and frequent foods in their diet. These must be taken into account in the planning of a social program. These results would justify elaborating a social program with a punctual and exclusive focus on food for the region, which in addition could be of high impact and effectiveness, not only in the municipality, but also in the amaranth producing zone of the state. However, it should be mentioned that what is advisable is to have an anthropometric diagnosis and an initial clinical one to complement the information and which can be the basis for a more punctual and prolonged follow-up. 
variaciones que se encontraron dentro de las familias no fueron necesariamente por su zona, sino por otros factores: características de las familias, como el número de hijos y los alimentos frecuentes en su dieta. Estos deben tenerse en cuenta en la planeación de un programa social. Estos resultados justificarían elaborar un programa social con enfoque alimentario puntual y exclusivo de la región, que además puede ser de alto impacto y efectividad, no solo en el municipio, sino en la zona productora de amaranto en el estado. No obstante, es preciso señalar que lo recomendable es contar con un diagnóstico antropométrico y uno clínico inicial que complementen la información y sean la base para un seguimiento más puntual y prolongado.

Se encontró que la mayoría de las familias son beneficiarias de algún programa social con enfoque alimentario; los programas identificados que se han implementado en el municipio fueron: Programa de Desarrollo Humano Oportunidades (PDHO), actualmente PROSPERA, Programa de Apoyo Alimentario (PAL), Programa de Abasto Rural (PAR), y Pensión para adultos mayores. Se puede decir que debido a su grado de vulnerabilidad la región cuenta con apoyos gubernamentales, estrategias en nutrición y programas con enfoque alimentario. Por lo tanto, la gente está acostumbrada a pertenecer a un programa, a cumplir con los requisitos y a recibir un apoyo en especie o efectivo. Sin embargo, la necesidad de un mejor diseño y planificación se hace evidente cuando las familias, a pesar de ser beneficiarias de ciertos programas alimentarios, poseen un grado de marginación alto y grado de rezago social medio (SEDESOL, 2013). Asimismo, se mantiene vigente la problemática de la desnutrición infantil pues, a pesar de los apoyos gubernamentales, en la zona rural prevalece el bajo peso $(8.0 \%)$ y la baja talla $(29.7 \%)$ entre infantes (Gutiérrez et al., 2012), un grupo de edad considerado como vulnerable (Vio et al., 2011). En este estudio se encontró un número considerable de posibles beneficiarios, ya que hay de dos a tres menores de edad en cada familia, lo que significa que un programa social con enfoque alimentario que centre su atención en este grupo de edad mejorará significativamente el bajo peso y la baja talla en la zona, incluso el nivel de vida de las familias (León-Corona, 2011).

Las poblaciones rurales están cambiando sus medios de vida pues hay factores que influyen en la descampesinización (Hocsman, 2014), fenómeno atribuible, entre otras causas, a la migración, el comercio y
It was found that most of the families are beneficiaries of some social program with a focus on food; the programs identified that have been implemented in the municipality were: Programa de Desarrollo Humano Oportunidades (PDHO), currently PROSPERA, Programa de Apoyo Alimentario (PAL), Programa de Abasto Rural (PAR), and Pensión para adultos mayores. It can be said that due to its degree of vulnerability the region has governmental backing, nutrition strategies, and programs with a focus on food. Therefore, the people are used to belonging to a program, to complying with the requirements and to receiving support in kind or cash. However, the need for a better design and planning is made evident when the families, despite being beneficiaries of certain food programs, have a high degree of marginalization and medium degree of social backwardness (SEDESOL, 2013). Likewise, the problem of child malnutrition remains valid since, despite the government supports, low weight $(8.0 \%)$ and low size $(29.7 \%)$ prevail in the rural zone among infants (Gutiérrez et al., 2012), a group of age considered as vulnerable (Vio et al., 2011). In this study a considerable number of possible beneficiaries was found, since there are two to three minors in each family, which means that a social program with a focus on food that centers its attention in this age group would significantly improve the low weight and the low size in the zone, even the standard of living of the families (León-Corona, 2011).

Rural populations are changing their livelihoods as there are factors that influence the depeasantization (Hocsman, 2014), a phenomenon attributable, among other causes, to migration, commerce and employment in other zones; however, this is not as evident among the population of the municipality of Tochimilco, for it was found that the prevailing livelihood in the municipality is agriculture, activity in which most of the members of the family nucleus are involved. The five most important crops were maize, bean, amaranth, avocado and broad bean. Of the survey respondents, $85 \%$ answered that they produce maize and that the production is destined basically to auto-consumption. All (100\%) sow white maize out of custom, taste and higher probability of sale. In terms of amaranth, $78 \%$ of the families said they produce it, in average, since eight years ago.

Although there is low, medium and high amaranth production, the differences are not great; 
empleo en otras zonas; sin embargo, esto no es tan evidente entre la población del municipio de Tochimilco, puesto que se encontró que el medio de vida preponderante en el municipio es la agricultura, actividad en la que se involucran la mayoría de los miembros del núcleo familiar. Los cinco cultivos más importantes fueron maíz, frijol, amaranto, aguacate y haba. El $85 \%$ de las encuestadas contestaron que producen maíz y que la producción se destina básicamente al autoconsumo. El 100 \% siembra maíz de color blanco por costumbre, gusto y mayor probabilidad de venta. En cuanto al amaranto, $78 \%$ de las familias dijeron producirlo, en promedio, desde hace ocho años.

Aunque existe producción baja, media y alta de amaranto, las diferencias no son grandes; la mayor parte del volumen de producción obtenido es para venta a los intermediarios, principalmente, lo que representa una fuente de ingreso económico de la mayoría de las familias. El amaranto es el tercer cultivo en importancia en el municipio y es preponderante para la economía familiar, ya que en el Estado de Puebla tiene mayor rentabilidad que en otros estados (\$5895.6 t $\left.t^{-1}\right)$, según Ayala et al. (2013). En el municipio de Tochimilco, al igual que en el resto del país, el maíz es el principal cultivo para la región y la base de la alimentación familiar (Fernández et al., 2013); tanto el maíz como el amaranto son de alta calidad en el aspecto nutricional, ya que aportan energía y aminoácidos esenciales (Aguilar et al., 2015), necesarios para las actividades fisiológicas vitales.

El amaranto es un recurso disponible con alta calidad nutricional y la combinación de este con otro alimento podría ser elemento clave para el desarrollo de un programa de alimentación que coadyuve a la nutrición familiar. La limitante es que la población no toma en cuenta al amaranto para incorporarlo a su alimentación diaria y únicamente se considera como un postre que aporta alto contenido de carbohidratos simples. Se observó que $66 \%$ de las encuestadas consume amaranto en forma de atole, dulce de alegría y tortitas, pero la mayor parte lo hace solo una vez por mes; es decir, el amaranto no es parte de la dieta habitual de los habitantes de Tochimilco. El Cuadro 2 presenta las razones principales por las que el amaranto no es parte de la dieta familiar en este municipio. La falta de información por parte de las encargadas del hogar es relevante, ya que la principal razón por la que no se consume como parte de la dieta regular de la familia en las tres comunidades fue most of the production volume obtained is for sale to intermediaries, primarily, which represents a source of economic income for most of the families. Amaranth is the third crop in importance in the municipality and it is predominantly for the family economy, since in the state of Puebla it has higher profitability than in other states $\left(\$ 5895.6 \mathrm{t}^{-1}\right)$, according Ayala et al. (2013). In the municipality of Tochimilco, just as in the rest of the country, maize is the main crop for the region and the basis of the family diet (Fernández et al., 2013); both maize and amaranth are of high quality in the nutritional aspect, since they contribute energy and essential amino acids (Aguilar et al., 2015), necessary for vital physiological activities.

Amaranth is an available resource with high nutritional quality and the combination of it with another food could be a key element for the development of a food program that contributes to family nutrition. The limiting factor is that the population does not take amaranth into account to incorporate it to its daily diet and is only considered as a desert that contributes a high content of simple carbohydrates. It was observed that $66 \%$ of the survey respondents consume amaranth in the form of atole (beverage), alegría sweets, and pancakes, but most only do it once a month; that is, amaranth is not a part of the habitual diet of Tochimilco inhabitants. Table 2 presents the main reasons why amaranth is not part of the family diet in this municipality. The lack of information of the female heads of household is relevant, since the main reason why it is not consumed as part of the regular diet of the family in three of the communities was they did not know how to prepare it. The results showed that the lack of knowledge of traditional amaranth cooking by those in charge of the family diet, of new dishes and alternative ways of cooking it, influence the consumption of this pseudo cereal in the study region, even when it is a resource that is available locally and which, therefore, is economically accessible.

In the population group studied, the female heads of family are the ones in charge of the family diet, just as was found in previous studies (Restrepo and Maya, 2005); according to the classification by Kotler \& Lee (2008), the female heads of family participated as the target audience of secondary type, since they influence the primary audience: the 
Cuadro 2. Razones mencionadas del bajo o nulo consumo de amaranto en tres localidades del municipio de Tochimilco, Puebla, México. 2015.

Table 2. Reasons mentioned of low or null amaranth consumption in three localities of the municipality of Tochimilco, Puebla, México. 2015.

\begin{tabular}{lccrr}
\hline \multicolumn{1}{c}{ Razón } & Tochimizolco & $\begin{array}{c}\text { San Miguel } \\
\text { Tecuanipa }\end{array}$ & $\begin{array}{c}\text { La Magdalena } \\
\text { Yancuitlalpan }\end{array}$ & Total \\
\hline Falta de costumbre & 5 & 2 & 2 & 9 \\
Es muy caro comprarlo & 1 & 2 & 0 & 3 \\
No sabe cocinarlo & 15 & 13 & 24 & 52 \\
No le gusta sabor o consistencia $_{\text {Falta de reventadora }}^{\dagger}$ & 1 & 0 & 0 & 1 \\
Otras razones $_{\text {Total }}$ & 2 & 2 & 2 & 6 \\
\hline
\end{tabular}

${ }^{\dagger}$ Máquina que tuesta la semilla de amaranto para su consumo. Machine that toasts the amaranth seed for its consumption.

el no saber prepararlo. Los resultados mostraron que la falta de conocimiento de la cocina tradicional del amaranto por parte de las encargadas de la alimentación familiar, de nuevos platillos y formas alternativas de cocinarlo, influye en el consumo de este pseudo cereal en la región de estudio, aun cuando es un recurso que está disponible localmente y que, por lo tanto, es accesible económicamente.

En el grupo poblacional estudiado, las madres de familia son las encargadas de la alimentación familiar, al igual que estudios previos (Restrepo y Maya, 2005); según la clasificación de Kotler \& Lee (2008), las madres de familia participan como audiencia objetivo de tipo secundario, ya que influyen en la audiencia primaria: los niños. Por lo tanto, tienen mayor posibilidad de incidir en la nutrición de sus hijos, aunque estas deben estar informadas para ser agentes de cambio en el estilo de vida. Galván y Atalah (2008) observaron que la escolaridad de la madre de familia está altamente vinculada con la dieta de los menores de edad, ya que a mayor grado de estudios tienen mejores conocimientos sobre la alimentación y salud familiar. En el presente estudio podemos apoyarnos en esta explicación para entender que el bajo aprovechamiento de recursos alimenticios de alto valor nutricional como el amaranto y la prevalencia de una dieta deficiente en vitaminas, minerales y proteínas de alto valor biológico (Figura 3) probablemente estén vinculados al bajo nivel educativo de las madres de familia; se puede inferir que están desvinculadas a conocimientos externos a la localidad y, debido a que los estudios son realizados dentro del mismo municipio, la población tiene limitaciones para acceder a información de otras instancias. children. Therefore, they have a higher possibility of influencing their children's nutrition, although they must be informed in order to be agents of change in the lifestyle. Galván and Atalah (2008) observed that the female heads of family's schooling is highly linked to the diet of the minors, since the higher degree of studies the better knowledge they have about the diet and family health. In this study we can lean on this explanation to understand that the low use of food resources of high nutritional value such as amaranth and the prevalence of a diet deficient in vitamins, minerals, and proteins of high biological value (Figure 3) is probably linked to the low educational level of the female heads of family; it can be inferred that they are disconnected from knowledge outside of the locality and, because the studies are carried out within the municipality, the population has limitations to gain access to the information from other instances.

The instrument Frequency of Consumption helps to discover food deficiencies and needs of the population. When applied in this study, the weekly mean consumption of foods in the population of Tochimilco was identified, specifically of preschooler and school children, shown in Figure 3. In it, the foods and dishes classified according to the food model of the Plato del Bien Comer, divulged in the Norma Oficial Mexicana 043 (NOM-043SSA2-2012), are presented; this model classifies the foods by colors according to the recommended level of consumption. It was observed that the foods of animal origin are not part of the patterns of food consumption of the families in the municipality of Tochimilco, and, as consequence, these do not 


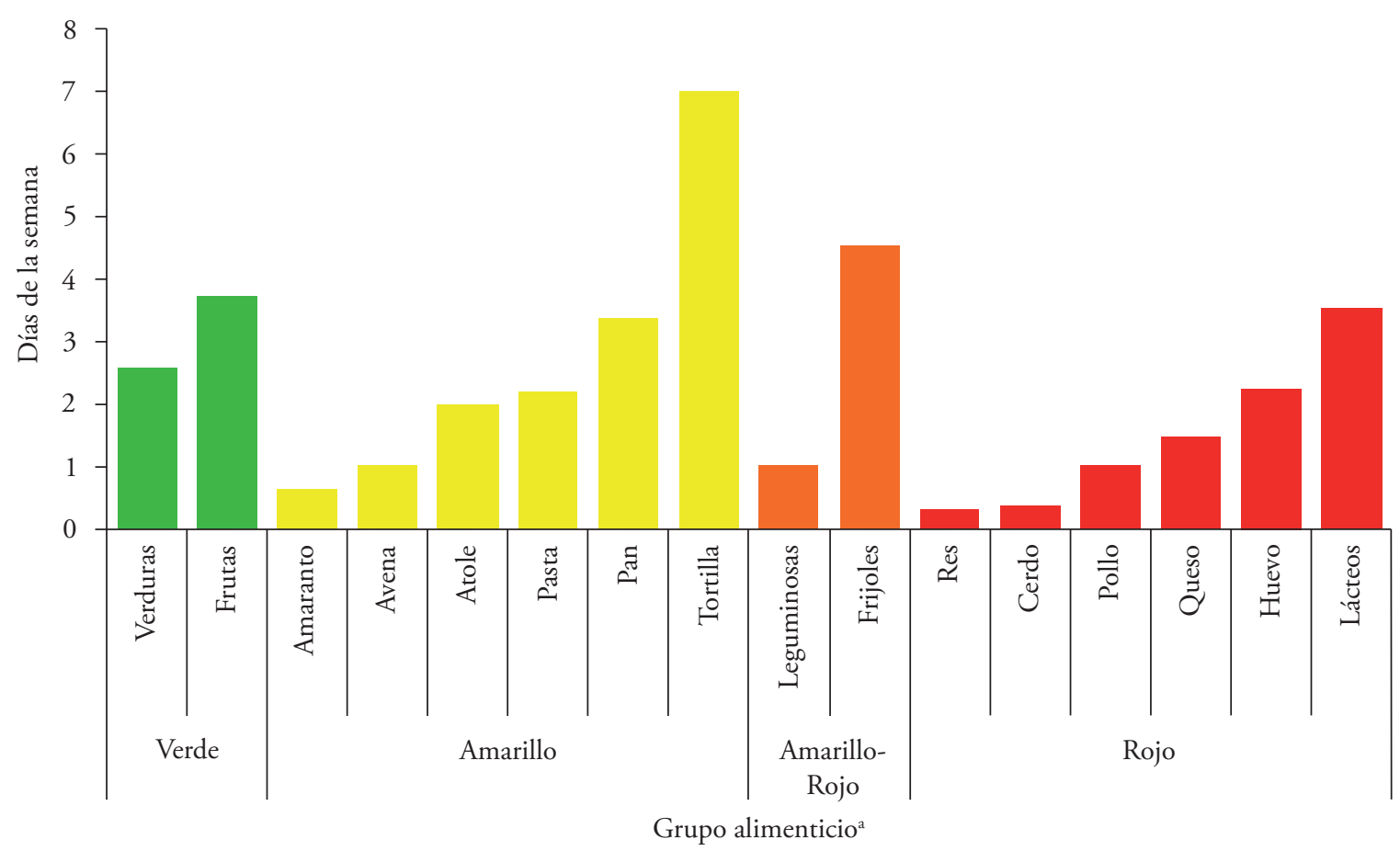

†Clasificación propuesta por la NOM-043-SSA2-2012. Classification proposed by NOM-043-SSA2-2012.

Figura 3. Frecuencia de consumo semanal por grupo de alimentos de las familias de Tochimilco, Puebla, México. 2015. Figure 3. Frequency of weekly consumption per food group of the families in Tochimilco, Puebla, México. 2015.

El instrumento Frecuencia de Consumo ayuda a descubrir deficiencias alimentarias y necesidades de poblaciones. Al aplicarse en este estudio se identificó la media del consumo semanal de alimentos de la población de Tochimilco, específicamente de preescolares y escolares, mostrado en la Figura 3. En esta se presentan a los alimentos y platillos clasificados de acuerdo con el modelo alimenticio del Plato del Bien Comer dado a conocer en la Norma Oficial Mexicana 043 (NOM-043-SSA2-2012); este modelo clasifica los alimentos por colores según el nivel recomendado de consumo. Se observó que los alimentos de origen animal no son parte de los patrones de consumo alimentario de las familias del municipio de Tochimilco y, en consecuencia, estas no alcanzan el aporte recomendado de proteínas y de energía, lo que es corroborado por Navarro-Meza et al. (2014). La ingesta de carne de res, cerdo, pollo, queso y huevo estuvo limitada a menos de tres días a la semana y los lácteos menos de cuatro veces semanalmente, por lo que es necesario cubrir esta deficiencia presente en la dieta habitual de la población objetivo. Los resultados indicaron que, por un lado, la dieta reach the recommended content of proteins and energy, which is corroborated by Navarro-Meza et al. (2014). The beef, pork, chicken, cheese and egg intake was limited to less than three days per week and dairy to less than four times per week, which is why it is necessary to cover this deficiency present in the habitual diet of the target population. The results indicated that, on the one hand, the family diet lacks vitamins, minerals and proteins of high biological value and that, on the other hand, it is based on the consumption of complex and simple carbohydrates, and is scarce in proteins of plant origin from beans. It was determined that the group of highest consumption was the yellow one; tortilla is the most highly consumed food by the families and for this reason it becomes a key element for the implementation of a program to increase protein intake, especially essential amino acids (Juan et al., 2007). Maize tortilla is the base of the daily diet, and it is consumed during many moments during the day. Because most of the population sows it, this crop becomes a locally available resource and of easy access for almost all the families in the study area. 
familiar carece de vitaminas, minerales y proteínas de alto valor biológico y que, por otro lado, está basada en el consumo de carbohidratos complejos y simples, y es escasa en proteínas de origen vegetal proveniente de los frijoles. Se determinó que el grupo con mayor consumo fue el amarillo; la tortilla es el alimento más consumido por las familias y por esta razón se convierte en un elemento clave para la implementación de un programa que aumente la ingesta de proteínas, especialmente de aminoácidos esenciales (Juan et al., 2007). La tortilla de maíz es la base de la alimentación diaria y se consume en varios momentos del día. Debido a que la mayoría de la población lo siembra, este cultivo se convierte en un recurso disponible localmente y de fácil acceso para casi todas las familias de la zona de estudio.

Es necesario resaltar que las familias tienen acceso directo a dos cultivos ricos en distintos aminoácidos esenciales, por lo que son fuente potencial de proteínas de alto valor biológico que coadyuvan en la eliminación de la desnutrición. El grano del amaranto alcanza niveles altos en algunos aminoácidos, respecto a la proteína ideal, cuyos valores se presentan en el Cuadro 3.

Asimismo, a través de los resultados se observó que la fruta y los frijoles pertenecen a la cultura alimentaria local y que son los dos alimentos con mayor relevancia después de la tortilla, pues se consumen entre tres y cinco días a la semana; por la frecuencia de consumo, ambos pueden ser enriquecidos con amaranto para incrementar su valor nutricional. A las frutas, además de ser fuente de fructosa, el añadirles amaranto las haría surgir como fuente proteica; en los frijoles, al ser fuente rica de proteínas, el amaranto potenciaría la calidad de aminoácidos esenciales. Si estos tres alimentos fueran enriquecidos con amaranto e incorporados a la dieta regular de la población en el municipio de Tochimilco, o de localidades similares en la región, obtendrían los beneficios nutricionales del amaranto, sin necesariamente modificar la ingesta de platillos a los que están acostumbrados.
It is necessary to highlight that the families have direct access to two crops rich in different essential amino acids, so they are a potential source of proteins of high biological value that contribute to eliminating malnutrition. The amaranth grain reaches high levels in some amino acids, compared to the ideal protein, whose values are shown in Table 3.

Likewise, through the results it was observed that fruit and beans belong to a local food culture and that they are the two foods with higher relevance after tortilla, since they are consumed three to five days per week; due to the frequency of consumption, both can be enriched with amaranth to increase their nutritional value. Adding amaranth to the fruits, in addition to being a source of fructose, would potentiate the quality of essential amino acids. If these three foods were enriched with amaranth and incorporated to the regular diet of the population in the municipality of Tochimilco, or of similar localities in the region, they would obtain the nutritional benefits of amaranth, without necessarily modifying the intake of dishes that they are used to.

When the principal factors analysis was carried out, it was found that the first three factors explained $63 \%$ of the total variation of the data. The explicative variables are presented in Table 4. In order to establish the determination of the principal factors with the original variables, an absolute value higher than 0.4 was taken into account in the coefficients derived from this analysis (without any rotation). According to this, factor 1 was related to the weekly frequency of consumption of some of the foods available to people, as well as to the variable related to the time that it takes them to produce amaranth. Factor 2 is related to the members of the family unit, who at the same time represent the potential beneficiary population of nutritional development strategies; finally, factor 3 is related to the minors who are members of a family unit and to the weekly consumption of proteins of plant origin that are important in the region: beans.

Cuadro 3. Balance de aminoácidos esenciales (gramo/100 gramos de aminoácidos esenciales en cada alimento). Table 3. Balance of essential amino acids (gram/100 grams of essential amino acids in each food).

\begin{tabular}{|c|c|c|c|c|c|c|c|c|}
\hline Concepto & Leucina & Fenilalanina & Lisina & Valina & Treonina & Isoleucina & Metionina & Triptofano \\
\hline Nivel de proteína ideal & 19 & 16 & 15.0 & 13 & 11 & 11 & 10 & 3 \\
\hline Amaranto (grano) & 15 & 5 & 1.2 & -2 & 11 & 10 & 11 & 2 \\
\hline
\end{tabular}

Fuente: Hernández y Herrerías, 1998. Source: Hernández and Herrerías, 1998. 
Al llevar a cabo el análisis de factores principales se encontró que los primeros tres factores explicaron $63 \%$ de la variación total de los datos. Las variables explicativas se presentan en el Cuadro 4. Para establecer la determinación de los factores principales con las variables originales se tomó en cuenta un valor absoluto superior a 0.4 en los coeficientes derivados de este análisis (sin rotación alguna). De acuerdo con lo anterior, el factor 1 se relaciona con la frecuencia de consumo semanal de algunos de los alimentos accesibles para las personas, así como la variable relacionada al tiempo que llevan produciendo amaranto. El factor 2 está relacionado con los integrantes de la unidad familiar, que al mismo tiempo representan a la población potencial beneficiaria de estrategias de desarrollo nutricional; finalmente, el factor 3 se relaciona con los menores de edad integrantes de la unidad familiar y con el consumo semanal de proteínas de origen vegetal importante en la región: los frijoles.

El conocimiento de estos factores facilitaría el diseño, difusión e implementación de un programa con enfoque alimentario, ya que estaría basado en la cultura de la alimentación local, en la cual el amaranto y los beneficios de su consumo fueran adoptados como parte de la dieta regular de la población en
The understanding of these factors would ease the design, dissemination and implementation of a program with a focus on food, since it would be based on the local diet culture, in which amaranth and the benefits of its consumption could be adopted as part of the regular diet of the population in the study region, especially part of the diet of the minors. Likewise, the program could be of lower cost than the current ones, in addition to being more effective, since the necessary resources would be within the community, minimizing transport costs.

\section{Conclusions}

The precise knowledge about the food culture and the consumption patterns of families of the study region are determinant to identify the factors that allow improving the nutritional health of the population; the strategies and programs may be designed according to these factors to improve their effectiveness. It was found that amaranth is consumed marginally among families of the study zone despite being an available resource and of easy access, situation that can be solved with greater information, food orientation and technological

Cuadro 4. Análisis de la estructura factorial (sin rotación) a partir de información de la alimentación familiar en tres localidades de Tochimilco, Puebla, México. 2015.

Table 4. Analysis of the factorial structure (without rotation) stemming from the information of the family diet in three localities of Tochimilco, Puebla, México. 2015.

\begin{tabular}{|c|c|c|c|}
\hline Factor & Variables originales & Coeficiente & Varianza explicada (\%) \\
\hline $\begin{array}{l}\text { Factor } 1 \\
\text { Alimentos accesibles }\end{array}$ & $\begin{array}{l}\text { Frecuencia de consumo de: } \\
\text { Verduras } \\
\text { Pollo } \\
\text { Huevo } \\
\text { Lácteos } \\
\text { Queso } \\
\text { Pan-bolillo } \\
\text { Pastas-arroz } \\
\text { Amaranto } \\
\text { Avena } \\
\text { Tiempo que lleva produciendo amaranto }\end{array}$ & $\begin{array}{l}0.430 \\
0.553 \\
0.458 \\
0.404 \\
0.448 \\
0.424 \\
0.413 \\
0.562 \\
0.559 \\
0.552\end{array}$ & 30 \\
\hline $\begin{array}{l}\text { Factor } 2 \\
\text { Población potencial }\end{array}$ & $\begin{array}{l}\text { Individuos en casa } \\
\text { Menores de edad en casa }\end{array}$ & $\begin{array}{l}0.608 \\
0.644\end{array}$ & 18 \\
\hline $\begin{array}{l}\text { Factor } 3 \\
\text { Ingesta de proteínas vegetales }\end{array}$ & $\begin{array}{l}\text { Menores de edad en casa } \\
\text { Frecuencia semanal de frijoles }\end{array}$ & $\begin{array}{r}-0.498 \\
0.409\end{array}$ & 15 \\
\hline 3 factores & 15 variables explicativas & & $63 \%$ \\
\hline
\end{tabular}


la región de estudio, especialmente parte de la dieta de los menores de edad. Asimismo, el programa podría ser de menor costo que los actuales, además de más efectivo, ya que los recursos necesarios estarían dentro de la comunidad, lo cual minimiza costos de transporte.

\section{Conclusiones}

El conocimiento preciso acerca de la cultura alimentaria y los patrones de consumo de las familias de la región del estudio es determinante para identificar los factores que permitan mejorar la salud nutricional de la población; las estrategias y los programas pueden diseńarse según estos factores para mejorar su efectividad. Encontramos que el amaranto se consume marginalmente entre las familias de la zona del estudio a pesar de ser un recurso disponible y de fácil acceso, situación que se puede resolver con mayor información, orientación alimentaria y capacitación tecnológica. Asimismo, los alimentos locales con mayor uso -la tortilla, frijoles y frutas- pueden ser vehículo del amaranto para mejorar la calidad de la nutrición de la población.

\section{Agradecimientos}

Se agradece a las autoridades municipales, auxiliares y educativas del municipio de Tochimilco y a las mujeres por el apoyo brindado, tiempo, confianza e información valiosa aportada, especialmente a las señoras Amelia Flores, Reyna Martínez y Gabriela Pérez. Un agradecimiento al Lic. Juan Velázquez por la elaboración de la Figura 1.

\section{Notas}

${ }^{3}$ INEGI define a la zona rural como aquellas localidades con población menor a 2500 habitantes. Estrada (1992) define la zona rural como el espacio donde se utiliza el suelo para producir alimentos. INEGI defines the rural zone as the localities with population of less than 2500 inhabitants. Estrada (1992) defines the rural zone as the space where the land is used to produce foods.

\section{Literatura Citada}

Alberich T., E. Sotomayor, T. Amezcua, y M. García-Domingo. 2014. Planificación, gestión y evaluación: manual básico training. Likewise, the local foods with highest use - tortilla, beans and fruits - may be a vehicle for amaranth to improve the quality of nutrition in the population.

\section{AKNOWLEDGMENTS}

We thank the municipal, auxiliary and educational authorities of the municipality of Tochimilco and the women for the support offered, time, trust, and valuable information contributed, especially the ladies Amelia Flores, Reyna Martínez and Gabriela Pérez. We thank Lic. Juan Velázquez for elaborating Figure 1.

- End of the English version -

para la Acción Social. 1a ed. Madrid, Dykinson, S.I., 2014.

Alcázar L. 2007. ¿Por qué no funcionan los programas alimentarios y nutricionales en el Perú?: riesgos y oportunidades para su reforma. In: Investigación, políticas y desarrollo en el Perú. $1^{a}$ ed. Lima: GRADE.

Aguilar E. G., G. J. Albarracín, M. A. Uñates, H. D. Piola, J. M. Camiña, and N. L. Escudero. 2015. Evaluation of the Nutritional Quality of the Grain Protein of New Amaranths Varieties. Plant Foods Hum Nutr. Núm. 70.

Ayala A. V., P. Rivas-Valencia, L. Cortes-Espinoza, M. Olán, D. Escobedo-López, y E. Espitia-Rangel. 2013. La rentabilidad del cultivo de amaranto (Amaranthus spp.) en la región centro de México. Ciencia ergo-sum. Vol. 21, Núm. 1.

Barquera S., J. Rivera-Dommarco, y A. Gasca-García. 2001. Políticas y programas de alimentación y nutrición en México. Salud Pública. Núm. 43.

Bracamontes J., M. Camberos, y L. Huesca. 2014. El impacto en los primeros ańos de aplicación del programa Oportunidades por tipo de pobreza en México y Baja California, 2002-2006. Estud. front. Vol. 15, Núm. 30.

CONAPO. 2010. Índice de marginación por localidad 2010.

CONEVAL. 2010. Medición de la pobreza.

De la Cruz J. L. 2013. La Cruzada Nacional contra el Hambre. Perspectivas. Núm. 2.

Diario Oficial de la Federación. 2013. Acuerdo por el que se emiten las Reglas de Operación del Programa de Desarrollo Humano Oportunidades, para el ejercicio fiscal 2014.

Diario Oficial de la Federación. 2014. Programa Nacional México Sin Hambre 2014-2018.

Estrada, F. 1992. Cambios en la concepción y en la organización del espacio rural. Estudios Regionales. Núm. 23.

Fernández R., L. A. Morales, y A. Gálvez. 2013. Importancia de los maíces nativos de México en la dieta nacional. Una revisión indispensable. Rev. Fitotec. Mex. Vol. 36, Supl. 3-A.

Galván M., y S. Atalah. 2008. Variables asociadas a la calidad de la dieta en preescolares de Hidalgo, México. Rev. Chil. Nutr. Vol. 35, Núm. 4. 
García-Parra E., H. Ochoa-Díaz-López, R. García-Miranda, L. Moreno-Altamirano, H. Morales, E. I. J. Estrada-Lugo, y R. Solís-Hernández. 2015. Estado nutricio de dos generaciones de hermanos(as) < de 5 años de edad beneficiarios(as) de Oportunidades en comunidades rurales marginadas de Chiapas, México. Nutr Hosp. Vol. 31, Núm. 6.

Gertler P. 2004. Do conditional cash transfers improve child health? Evidence from PROGRESA's control randomized experiment. The American Economic Review. Vol. 94, Núm. 2.

Godfray H. C. J., J. R. Beddington, I. R. Crute, L. Haddad, D. Lawrence, J. F. Muir, J. Pretty, S. Robinson, S. M. Thomas, and C. Toulmin. 2010. Food security: The challenge of feeding 9 billion People. Science. Vol. 327, Núm. 812.

González C. G., I. Zacarías, A. Domper, L. Fonseca, L. Lera, y F. Vio. 2014. Evaluación de un programa de entrega de frutas con educación nutricional en escuelas públicas rurales de la Región Metropolitana, Chile. Rev Chil Nutr. Vol. 41, Núm. 3.

Gutiérrez J. P., J. Rivera-Dommarco, T. Shamah-Levy, S. Villalpando-Hernández, A. Franco, I. Cuevas-Nasu, M. RomeroMartínez, y M. Hernández-Ávila. 2012. Encuesta Nacional de Salud y Nutrición 2012. Resultados Nacionales. Cuernavaca, México:Instituto Nacional de Salud Pública.

Härdle W., and L. Simar. 2007. Applied Multivariate Statistical Analysis. 2a ed. Berlin Heidelberg New York: Springer.

Hernández G. R., y G. G. Herrerías. 1998. Amaranto: Historia y promesa. Tehuacán: Horizonte del Tiempo Vol. 1. México: Patrimonio Histórico de Tehuacán.

Hocsman, L. 2014. Agricultura Familiar y descampesinización. Nuevos sujetos para el desarrollo rural modernizante. Perspectivas Rurales Nueva Época. Núm. 13.

INEGI. 2010. Censo de Población y Vivienda, 2010. Marco Geoestadístico Municipal.

Juan R., J. Pastor, M. Alaiz, C. Megías, y J. Vioque. 2007. Caracterización proteica de las semillas de once especies de amaranto. Grasas y aceites. Vol. 58, Núm. 1.

Kotler P., and N. R. Lee. 2008. Social Marketing: Influencing behaviors for good. 3 a ed. USA: Sage Publications.

León-Corona, B. 2011. ¿Redención o conducción? Los efectos del Programa Oportunidades en los pobres. Polít. Cult. Núm. 35

Marín G. A., M. C. Álvarez, y J. Rosique. 2004. Cultura alimentaria en el municipio de Acandí. Boletín de Antropología Universidad de Antioquía. Vol. 18, Núm. 35.

Martínez-Salgado C. 2012. El muestreo en investigación cualitativa. Principios básicos y algunas controversias. Ciência \& Saúde Colectiva. Vol. 17, Núm. 3.

Medina I., y Á. Florido. 2010. Microcrédito y desarrollo: financiamiento de proyectos sociales. Espiral, Estudios sobre Estado y sociedad. Vol. 16, Núm. 47.

Mishra S., J. Xu, U. Agarwal, J. Gonzales, S. Levin, and N. D. Barnard. 2013. A multicenter randomized controlled trial of a plan-based nutrition program to reduce body weight and cardiovascular risk in the corporate setting: the GEICO study. Eur J Clin Nutr. Vol. 67, Núm 7.
Miller G., R. Luo, L. Zhang, S. Sylvia, Y. Shi, and P. Foo. 2012. Effectiveness of provider incentives for anaemia reduction in rural China: a cluster randomized trial. BMJ. Vol. 345, Núm. e4809.

Navarro-Meza M., A. G. Martínez, A. López-Espinoza, P. LópezUriarte, M. R. Benavides. 2014. Comparación en la ingesta de alimentos de adultos que residen en una zona rural y urbana de Jalisco, México. Revista Mexicana de Trastornos Alimentarios. Núm. 5.

Pérez G. R. S., L. A. Vega-García, y G. Romero-Juárez G. 2007. Practicas alimentarias de mujeres rurales: ¿una nueva percepción del cuerpo? Salud Pública Mex. Vol. 49, Núm. 1.

Pineda B. C. 2012. Desarrollo humano y desigualdades en salud en la población rural en Colombia. Univ Odontol. Vol. 31, Núm. 66.

Quintero J. C., H. Cardona, Y. B. Rodríguez, J. Rolong, y M. L. Salas. 2014. Diagnóstico situacional de las condiciones importantes y necesarias para la implementación de Redes Integradas de Servicios de Salud (RISS) basadas en Atención Primaria en Salud (APS) en el departamento de Huila. Entornos. Núm. 27.

Restrepo, S. L., y M. Maya-Gallego. 2005. La familia y su papel en la formación de los hábitos alimentarios en el escolar. Un acercamiento a la cotidianidad. Boletín de Antropología Universidad de Antioquía. Vol. 19, Núm. 36.

Rivera-Dommarco, J. A., L. Cuevas-Nasu, T. González de Cosío, T. Shamah-Levy, y R. García-Feregrino. 2013. Desnutrición crónica en México en el último cuarto de siglo: análisis de cuatro encuestas nacionales. Salud Pública de México. Vol. 55, Supl. 2.

Ruel M. T., y H. Alderman. 2013. Nutrition-sensitive interventions and programmes: how can they help to accelerate progress in improving maternal and child nutrition? The Lancet. Vol. 382, Núm. 9891.

Sánchez-Olarte, J., A. Argumedo-Macías, J. F. Álvarez-Gaxiola, J. A. Espinoza, B. Ortiz-Espejel. s/f. Acta universitaria. Artículo en arbitraje.

SEDESOL. 2011. Atlas de riesgos del municipio de Tochimilco. Constructira Grucogomm S. A. de C. V.

SEDESOL. 2012. Diagnóstico integral de los programas alimentarios de la SEDESOL.

SEDESOL. 2013. Catálogos de localidades.

SIAP. 2014. Cierre de la producción agrícola por estado.

SAS (Statistical Analysis Software). 2004. SAS/STAT. Versión 9.1. North Caroline, USA: SAS Institute Inc.

Timm N. H. 2002. Applied Multivariate Analysis. $1^{\text {a }}$ ed. New York: Springer-Verlag New York Inc.

Urzúa A., A. Caqueo-Urízar, N. Albornoz, y C. Jara. 2013. Calidad de vida en la infancia: estudio comparativo entre una zona rural y urbana en el norte de Chile. Rev Chil Pediatr. Vol. 84, Núm. 3.

Vilaplana M. 2011. Cultura alimentaria. Del fast food al slow food. Offarm. Vol. 30, Núm. 6.

Vio F., I. Zacarías, L. Lera, C. Benavides, y A. Gutiérrez. 2011. Prevención de obesidad en escuelas básicas de Peñalolén: componente alimentación y nutrición. Rev Chil Nutr. Vol. 38, Núm. 36. 